\title{
Sir Benjamin Ward Richardson and the Jews
}

\author{
By Erwin H. Ackerknecht $\dagger$
}

In the course of researches concerning the history of causal theories in pathology, I perused Sir Benjamin Ward Richardson's interesting Diseases of modern life (1876). There I read, in connection with the author's thesis that the "removal of excessive physical endurance tends to health and length of life", that the "most striking fact of this kind is afforded in the history of the Jewish race... In no period of the history of this wonderful people since their dispersion we discover [etc.]". ${ }^{1}$ What stopped me here was not any question as to whether the Jews are wonderful or not (in my opinion they are as wonderful, or not, as all humans); but that for the first time in a long life I had encountered such a statement committed to print by an eminent Christian medical man. Who was Sir Benjamin Ward Richardson, and what could have induced him to make this remark?

He was born in 1828 in Somerby, Rutland, and died in London in $1896^{2}$. After an apprenticeship he acquired the licence of the Glasgow Faculty of Physicians and Surgeons in 1853. After working in Mortlake, he graduated as an MD from St Andrews University in 1854, and then settled in London where he practised, researched, taught, wrote and lectured for the rest of his life. According to the Dictionary of national biography he was one of the "most prolific writers of his generation". ${ }^{3}$ His hospital- and teaching connections were both honorable and numerous, including the Royal Hospital for Diseases of the Chest, and St George's School of Medicine. He became a Member of the Royal College of Physicians in 1856, a Fellow of the same College in 1865, a Fellow of the Royal Society in 1867, and was knighted in 1893. President of numerous British societies, he was an honorary member of others in Germany, America, France, Italy and other countries.

Richardson, one of the pioneers of the Sanitary Movement and an advocate of preventative medicine was, not coincidentally, a close friend of Edwin Chadwick, William Farr and John Snow. He published half a dozen books and numerous papers in this connection and founded the Journal of Public Health and Sanitary Review, the first in the field, in 1855. His optimism concerning victories over infectious diseases has been, by and large, confirmed by history. He began with cholera studies. In his Utopia 
Hygieia, a city of health (1876) he described a city without air pollution. He asked for a Ministry of Health, and for compulsory public instruction in preventative medicine. He was a co-founder of the Epidemiological Society, and the Sanitary Inspectors' Society. He was particularly active in that important branch of preventative medicine, the fight against alcohol in what he called an "alcoholic world". He became a teetotaler relatively late; typically, he made the decision not on ethical grounds but on the basis of his animal experimentation. He also did experimental research on tobacco.

He was particularly interested in anaesthesia, and found fourteen anaesthetics: the only known method of local anaesthesis until the advent of cocaine for this purpose in 1884 was the Richardson ether spray. He was the first to warn against the habit-forming character of chloralhydrate. His familiarity with anaesthetics led to his involvement in the movement for the improvement of slaughter-houses; he invented the "lethal chamber" for the painless destruction of animals which had to be killed.

Richardson's interest in drugs was not limited to anaesthetics. He used amyl nitrite in the treatment of angina pectoris before Lauder Brunton did. He promoted iodine and hydrogen peroxide as disinfectants. For the treatment of pulmonary tuberculosis, however, he recommended not drugs but "natural methods"; he was also an early enthusiast for bicycling.

A few years ago, W. F. Bynum drew attention to Richardson's early work on the relation of molecular structure to pharmaceutical action ${ }^{4}$; Richardson also experminted with blood coagulation.

Richardson was not only a prolific scientific writer, but a playwright, novelist, poet and historian of some ability. In 1858 he became a member of a literary club together with Thackeray, the cartoonist Cruikshank and Lennon, the founder of Punch.

Several reasons might be adduced why this man of so many accomplishments, who played an important role in his time, has now been so thoroughly forgotten. He would certainly be better remembered had he specialized, instead of contributing to so many fields. His popular science-writing may have caused him to lose caste among the specialist, scientific dullards. It was important that he never accepted bacteriology, the science of the future; last, but not least, he fought against alcohol in a society which only slowly became less alcoholic.

Wherein lay the roots of Richardson's obvious enthusiasm for the Jewish people (or "race" as he called them in the manner of the day)? At least part of it resulted from his findings (based on poor statistics) that they were "of all 
civilised races the first in vitality", ${ }^{5}$ that is, in resistance to those influences which tend to shorten the natural life cycle ${ }^{6}$. In his opinion, this high degree of vitality resulted from a cultural sobriety which included sound nutrition; early marriage; and attentiveness to the care of children, the aged and the poor. This opinion was by no means accepted by all Jewish doctors ${ }^{7}$, but Richardson lectured widely on this theme, to both Jews and Christians ${ }^{8}$ and on this basis he seems to have developed cordial relations with the Jewish community.

Richardson lived at a time when the lives of British Jews had become different from those in the rest of Europe. Poliakow described their situation in his History of antisemitism: "Once they had been acquired, the political rights of the Jews in Great Britain were never again questioned in the same way, as the Jews there were spared the crises and antisemitic campaigns which raged practically everywhere in Europe in the second half of the nineteenth century". ${ }^{9}$ By way of explanation for these and other manifestations of this "low ebb of English antisemitism" Poliakow offers the religious affinity between Jews and English Nonconformists who sought guidance and justification in the Old Testament. Richardson's first name was "Benjamin"; the popularity of Old Testament given names among the English is not confined to the present day.

Among other factors Poliakow mentions the pride of the English, who were not paranoically frightened of the Jews; the lack of a politically radical tradition among English Jews; and the affinities between Jewish and English fiscal ethics. Nineteenth-century English literature indeed produced no Shylock, but such attractive heroines as those of Sir Walter Scott. England defended the interests of the dispersed nation on many occasions, and British writers discussed the idea of a Jewish state long before Theodor Herzl.

This relatively benign atmosphere in England had developed slowly. The Board of Deputies of British Jews was founded in 1760, earlier than those in other European countries ${ }^{10}$, missionary work among the Jews had also been underway for a long time by Richardson's day.

Another possibility is, of course, that Richardson's personal attitude towards the Jews was influenced by family connections, or friendships like that between Hitzig and Chamisso in Prussia, although no such relationship is known to have existed for Richardson, his wife (née Mary Smith), his sons Bertram and Aubrey, or his daughter Mary Sheila, wife of the Reverend George Martin. Was there any connection with philosemitic Dissenters? 
Richardson never mentioned his own religion, but described his mother as belonging to a Calvinist sect ${ }^{11}$. Richardson counted the Quaker Hodgkin among his friends; and in his autobiography Vita medica referred to his closest friend, Chadwick, who came from an old Wesleyan Methodist family, as approving his ideas about the level of health among the Jews ${ }^{12}$. The only Jewish friend mentioned in that long book is Henry Hirschfeldt ${ }^{13}$.

But Richardson was the contemporary of Benjamin Disraeli, Lord Beaconsfield (1804-1881) ${ }^{14}$. The descendant of a wealthy Marano family, Disraeli's father had him baptized in 1817. Known first as a snob and a novelist, Disraeli then turned politician and was elected as a Tory in 1837 to the House of Commons. There he rose to become the leader of his party, and Prime Minister in 1868 and from 1874 to 1880 . He was a very successful statesman and, in spite of his strange personality, became as popular with the masses ("Dizzy") as he was with his Queen. Richardson met him by accident, as a schoolboy, and had repeated meetings with him twenty years later ${ }^{15}$.

Richardson could have borrowed some of his ideas on the Jews from Disraeli, who expressed his own most extensively in the novel Tancred (1847). "All is race. Civilisation is the result of the 'Arabian principle' of which the Jews were the first incarnation. Christianism is Judaism for the multitude. All great men were Jews." ${ }^{16}$ He defended the same principles not only in novels, but in Parliament, in the year of Tancred's publication. Poliakow wrote with some justice that "Maurois like all Disraeli biographers takes care not to overemphasize his Judeomania". ${ }^{17}$ [?]

We do not know what Richardson thought about the Prime Minister's ideas. But we may be certain that they were in complete agreement on another issue: public health. Disraeli, too, was a great public-health reformer. "The first consideration of a Minister should be the health of the people". ${ }^{18}$ And he practised what he preached. His enemies might mock his "policy of sewage"; ${ }^{19}$ but Disraeli cleaned the Thames in $1858^{20}$, and his return to power in 1874 heralded a wave of reform including a public health act. Thus it seems possible that at the bottom of Benjamin Richardson's unique statement was the Marano Benjamin Disraeli. 


\section{Footnotes}

1 Benjamin Ward Richardson, Diseases of modern life, third ed., London, Macmillan, 1876, pp. 168-69. Emphasis mine.

2 The best biography of Richardson is still that by Sir Arthur S. MacNalty, A biography of Sir Benjamin Ward Richardson, London, Harvey \& Blythe, 1950.

3 DNB, vol. 22 (Supplement), s.v. 'Richardson, Sir Benjamin Ward'.

4 W. F. Bynum, "Chemical structure and pharmacological action: a chapter in the history of 19th-century molecular pharmacology', Bull. Hist. Med., 1970, 44: 518-38.

5 Richardson, op. cit., note 1 above, p. 169.

6 Ibid., pp. 19-25.

7 Harry Friedenwald, The Jews and medicine, 2 vols., Baltimore, The Johns Hopkins Press, 1944, vol. 2 , pp. $525 \mathrm{ff}$.

8 Benjamin Ward Richardson, Vita medica: chapters of medical life and work, London, Longmans, Green \& Co., 1897, p. 255.

9 Léon Poliakov, The history of anti-semitism, vol.3, London, Routledge \& Kegan Paul, 1975, p. 323.

10 C. W. Crawley (editor), War and peace in an age ofe upheaval, 1793-1830, vol.9, The New Cambridge Modern History, Cambridge University Press, 1965, p. 244.

11 Richardson, op. cit., note 8 above, p. 13.

12 Ibid., p. 255.

13 Ibid., p. 143.

14. A good biography of Disraeli is Hesketh Pearson, Dizzy: the life and nature of Benjamin Disraeli, Earl of Beaconsfield, London, Methuen, 1951.

15 Richardson, op. cit., note 8 above, pp. 20-24.

16 Benjamin Disraeli, Tancred: or, the new crusade, 3 vols., London, Henry Colburn, 1847, pp. 191, 159, 335 .

17 Poliakov, op. cit., note 9 above, p. 333.

18 Winston Churchill, A history of the English-speaking peoples, vol.4, The great democracies, London, Cassell, 1958, p. 229.

19 Ibid.

20 Pearson, op. cit., note 14 above, p. 170. 